\title{
FAKTOR-FAKTOR YANG MEMENGARUHI PENENTUAN JUMLAH ANAK DALAM KELUARGA DI KECAMATAN BUKIT KABUPATEN BENER MERIAH
}

\author{
${ }^{1}$ Nurlaely. HS \\ ${ }^{2}$ Rahma Yani \\ Program Studi D III Kebidanan Stikes Payung Negeri Aceh Darussalam \\ e-mail: ${ }^{1}$ nurlaely851@gmail.com, ${ }^{2}$ mayaabdurrahman01@ gmail.com
}

\begin{abstract}
ABSTRAK
Indonesia merupakan salah satu negara yang memiliki banyak masalah kependudukan yang hingga saat ini belum bisa diatasi. Pengendalian merupakan suatu upaya atau kegiatan membatasi pertumbuhan penduduk, dengan mengurangi jumlah kelahiran. Kebijaksanaan kependudukan dikenal dengan program Keluarga Berencana (KB). Penelitian ini bertujuan untuk mengetahui pengaruh faktor-faktor terhadap penentuan jumlah anak dalam keluarga di Kecamatan Bukit Kabupaten Bener Meriah. Jenis penelitian ini adalah survey analitik dengan pendekatan crosssectional. Penelitian ini dilakukan pada bulan Januari 2020. Populasi sebanyak 13.618 orang. Jumlah sampel sebanyak 99 orang. Analisis data multivariat menggunakan uji logistic regression. Hasil penelitian diperoleh bahwa bahwa faktor dukungan keluarga, sosial budaya/kepercayaan, ekonomi, nilai anak dan penggunaan kontrasepsi berhubungan dengan penentuan jumlah anak dalam keluarga dan variabel sosial budaya adalah variabel yang paling dominan berpengaruh terhadap penentuan jumlah anak dalam keluarga dengan nilai $\operatorname{Exp}(\mathrm{B})$ 23,009 (CI : 95\%, 5,193-101,935).
\end{abstract}

Kata Kunci : Dukungan Keluarga ; Sosial Budaya/Kepercayaan ; Ekonomi ; Nilai Anak ; Penggunaan Kontrasepsi ; Penentuan Jumlah Anak

\begin{abstract}
Indonesia is one country that has many population problems that until now can not be overcome. Control is an attempt or activity to limit population growth, by reducing the number of births. Population policy is known as Family Planning (KB) program. This study aims to determine the effect of factors on the determination of the number of children in the family in Bukit District Bener Meriah regency. This research type is analytic survey with cross sectional approach. This study was conducted from January 2020. The population is 13,618 people. The number of samples is 99 people. Multivariate data analysis using logistic regression test. The result showed that family support factor, socio-cultural I belief, economy, child value and contraceptive use were related to the determination of the number of children in the family and socio-cultural variables is the most dominant variable affecting the determination of the number of children in the family with the value of Exp (B) 23.009 (CI: 95\%, 5,193101,935).

Keywords : Family Support ; Socio-Culture Trust ; Economy ; Child value ; Contraceptive use ; Determination of number of children
\end{abstract}

\section{PENDAHULUAN}

Penduduk merupakan modal dasar dalam mewujudkan tujuan pembangunan suatu bangsa dan negara. Penduduk yang besar dan berkualitas merupakan investasi yang berharga bagi suatu negara dengan produktifitasnya yang tinggi. Namun 
sebaliknya penduduk yang besar namun tidak berkualitas hanya akan menjadi beban negara, karena produktifitas ditentukan oleh pendidikan, status kesehatan/gizi dan penghasilan. Penduduk dengan pendapatan perkapita rendah akan terbatas untuk memenuhi kebutuhan gizi dan pelayanan kesehatan yang secara langsung berdampak pada Sumber Daya Manusia (SDM) yang rendah dan produktivitas $(\mathrm{BKKBN}, 2012)$

Masalah pertumbuhan penduduk yang tinggi mempunyai implikasi yang luas terhadap tujuan pembangunan nasional, mulai dari pendidikan, kesehatan tenaga kerja,sandang,pangan, dan papan serta keamanan. Pertumbuhan penduduk yang baik merupakan keseimbangan dinamis antara faktor yang menambah (kelahiran) dan mengurangi (kematian), berarti salah satu faktor pertumbahan penduduk ditentukan oleh kelahiran, kematian dan migrasi yang dilakukan oleh penduduk. Hal ini berarti faktor kelahiran yang menyebabkan tingginya laju pertumbuhan penduduk (Zainuddin, 2011)

Berdasarkan Survei Demografi Kesehatan Indonesia (SDKI) pada tahun 2012, diketahui bahwa persentase wanita yang sedang hamil dengan kategori usia 15-49 tahun meningkat dari 3,9\% di tahun 2007 menjadi $4,3 \%$ pada tahun 2012 , demikian pula PUS yang memiliki 1-2 anak menurun dari 64,3\% menjadi 63,2\%. Kebutuhan PUS (20-24 tahun) terhadap ber KB juga menurun $71,5 \%$ menjadi $68,6 \%$, pada umur 25-29 tahun turun dari 74,0\% menjadi $71,9 \%$ selanjutnya pada umur $30-34$ tahun terjadi penurunan yang lebih besar dari $78,5 \%$ menjadi $74,1 \%$. Data-data tersebut menunjukkan bahwa persentase keikutsertaan PUS menjadi akseptor KB semakin sedikit/menurun, yang berkaitan dengan peningkatan Total Fertility Rate) dan LPP (Laju Pertumbuhan Penduduk) di Indonesia (BKKBN, 2010)
Menurut data proyeksi BPS (Badan Pusat Statistik) penduduk Indonesia di tahun 2035 diproyeksi sebesar 305,6 juta jiwa. Dalam proyeksi 2000-2025, jika dibandingkan dengan hasil lapangan Sensus Penduduk 2010 terdapat selisih 3,5 juta, dimana jumlah penduduk tahun 2010 diproyeksikan 234 juta jiwa, namun pada kenyataannya mencapai angka 237,6 juta jiwa. Proyeksi 2000-2010 menggunakan asumsi angka kelahiran sebesar 2,1 pada tahun 2015, namun sampai saat ini angka kelahiran nyatanya stagnan di 2,6. Hasil proyeksi ini dapat digunakan untuk investasi jangka panjang pemerintah. Isu kependudukan yang paling menarik salah satunya adalah bonus demografi. Sebuah negara dikatakan mengalami bonus demografi jika dua orang penduduk usia produktif (15-64) menanggung satu orang penduduk tidak produktif (kurang dari 15 tahun dan 65 tahun atau lebih). Indonesia, menurut perhitungan, sudah mengalami bonus demografi sejak tahun 2012, dan puncaknya akan terjadi di tahun 2028-2030. Bonus demografi ini jika dikelola dengan baik maka akan diuntungkan untuk penyediaan tenaga kerja, jika tidak dikelola dengan baik maka bisa menjadi musibah, misalnya kesempatan kerja yang terbatas, pengangguran, dan konflik social (Dinkes, 2017)

Hasil Riset Kesehatan Dasar (Riskesdas) tahun 2013 diketahui banyak alasan yang dikemukakan oleh wanita yang tidak menggunakan kontrasepsi adalah : menginginkan anak $(46,6 \%)$, tidak ingin menggunakan alat kontrasepsi $(15,7 \%)$, takut efek samping $(11,0 \%)$, fertilitas (7,0\%), dilarang suami/keluarga $(6,1 \%)$. Tidak nyaman $(5,2 \%)$, kurang pengetahuan $(3,4 \%)$, kepercayaan/dilarang agama $(3,3 \%)$ dan masalah akses alat KB $(1,4 \%)$ (Riskesdas, 2013)

Penelitian Singarimbun mengenai nilai anak pada masyarakat Jawa dan Sunda, menemukan adanya variasi nilai anak 
berdasarkan pandangan orang tuanya baik dari segi ekonomi, sosial maupun psikologis. Nilai tersebut juga bervariasi menurut tempat tinggal. Orang tua yang tinggal di desa mempunyai nilai yang berbeda terhadap anak bila dibandingkan dengan orang tua yang tinggal di kota. Hasil penelitian Hartoyo mendapatkan hasil bahwa jumlah anak yang diinginkan keluarga dipengaruhi oleh besar keluarga, sementara itu keikutsertaan keluarga dalam program KB sebagian besar ditentukan oleh ibu. Keikutsertaan keluarga dalam program $\mathrm{KB}$ dipengaruhi oleh usia menikah pertama ibu dan selisih jumlah anak yang dilahirkan dengan jumlah anak yang diinginkan. Pada kelompok non akseptor $\mathrm{KB}$, jumlah anak yang lahir hidup telah sesuai dengan jumlah anak yang diinginkan.

Penelitian Fitria Kesuma, partisipasi masyarakat dalam mengikuti program keluarga berencana di desa Sidoarjo kecamatan Polanharjo Kabupaten Klaten bahwa adanya persepsi KB merupakan kewajiban perempuan, selama kondisi perempuan memungkinkan untuk ber-KB, KB hanya dapat dilakukan dengan menggunakan alat kontrasepsi yang dipilih dan digunakan sesuai kecocokan terhadap diri akseptor, dan beberapa alat kontrasepsi menakutkan bagi akseptor seperti IUD, implant dan sterilisas (Kesuma Fitria, 2010)

Kecamatan Bukit merupakan salah satu kecamatan yang terletak di Kabupaten Bener Meriah, keadaan alam Kecamatan Bukit adalah daerah tinggi, masyarakat Kecamatan Bukit merupakan masyarakat homogen dengan suku Gayo.Kecamatan Bukit memiliki bahasayang digunakan sesuai dengan sukunya. Jumlah penduduk Kabupaten Bener Meriah pada tahun 2016 sebanyak 689.117 jiwa, 134.188 KK yang tersebar dalam 9 Kecamatan, mencakup 98 Kelurahan dan Desa. Jumlah Pasangan Usia Subur (PUS) Kabupaten Labuhanbatu pada tahun 2016sebanyak 82.801 pasangan, jumlah Kepala Keluarga (KK) 134.188 sementara jumlah peserta KB tahun 2016 tercatat 60.816 pasangan. Jumlah penduduk Kecamatan Bukit pada tahun 2016 adalah 21.619 jiwa dan jumlah Pasangan Usia Subur (PUS) untuk Kecamatan Bukit 6.556 pasangan, sementara jumlah Kepala Keluarga sebanyak 8.297 dengan peserta Keluarga Berencana (KB) 6.688 pasangan. Kabupaten Bener Meriah merupakan Kabupaten yang mengalami masalah kependudukan terutama pada daerah-daerah yang jauh dipedalaman. Tingkat pertumbuhan penduduk yang melebihi anjuran pemerintah melalui program Keluarga Berencana (KB) dapat dijumpai di Kecamatan Bukit.

\section{METODE PENELITIAN}

Jenis penelitian yang digunakan adalah survei analitik dengan menggunakan pendekatan cross sectional. Penelitian akan dilakukan di Kecamatan Bukit Kabupaten Bener Meriah.

Waktu penelitian telah dilakukan pada tanggal 02 sampai dengan 31 Januari tahun 2020. Populasi dalam penelitian ini adalah seluruh PUS yang tercatat maupun terdaftar dan bertempat tinggal di Kecamatan Bukit Kabupaten Bener Meriah yaitu sebanyak 13.618 orang.

Pengambilan sampel pada penelitian ini menggunakan teknik random sampling. Besar sampel pada penelitian ini berjumlah 99 responden dan penentuan sampel dengan cara mengundi populasi dan nama yang keluar kemudian menjadi sampel pada penelitian. Kemudian untuk penarikan sampel digunakan teknik cluster sampling. Analis data multivariat menggunakan uji logistic regression.

\section{HASIL DAN PEMBAHASAN}


Hasil penelitian yang dilakukan terhadap 99 responden untuk mengetahui apakah ada faktor-faktor yang mempengaruhi penentuan jumlah anak dalam keluarga di Kecamatan Bukit Kabupaten Bener Meriah adalah sebagai berikut :

\section{A. Univariat}

\section{Dukungan Keluarga}

Tabel 1. Distribusi Frekuensi Dukungan Keluarga di Kecamatan Bukit Kabupaten Bener Meriah

\begin{tabular}{c|c|c|c} 
No & Dukungan Keluarga & $\mathbf{f}$ & $\boldsymbol{\%}$ \\
\hline 1. & Mendukung & 38 & 38,4 \\
2. & Tidak Mendukung & 61 & 61,6 \\
\hline & Total & $\mathbf{9 9}$ & $\mathbf{1 0 0}$
\end{tabular}

Berdasarkan data dari tabel diatas menunjukkan bahwa dari 99 responden PUS diperoleh dukungan suami termasuk dalam kelompok mendukung sebanyak 38 orang $(38,4 \%)$ dan termasuk dalam kelompok tidak mendukung yaitu sebanyak 61 orang $(61,6 \%)$.

\section{Sosial budaya/kepercayaan}

Tabel 2. Distribusi Frekuensi Sosial Budaya/Kepercayaan di Kecamatan Bukit Kabupaten Bener Meriah

\begin{tabular}{c|c|c|c} 
No & $\begin{array}{c}\text { Sosial Budaya } \\
\text { /Kepercayaan }\end{array}$ & $\mathbf{f}$ & $\mathbf{\%}$ \\
\hline 1. & Mendukung & 42 & 42,4 \\
2. & Tidak Mendukung & 57 & 57,6 \\
\hline & Total & $\mathbf{9 9}$ & $\mathbf{1 0 0}$
\end{tabular}

Berdasarkan data dari tabel diatas menunjukkan bahwa dari 99 responden PUS diperoleh sosial budaya/kepercayaan termasuk dalam kelompok mendukung sebanyak 42 orang $(42,4 \%)$ dan termasuk dalam kelompok tidak mendukung yaitu sebanyak 57 orang $(57,6 \%)$.

\section{Ekonomi}

Tabel 3. Distribusi Frekuensi Ekonomi di Kecamatan Bukit Kabupaten Bener Meriah

\begin{tabular}{c|c|c|c} 
No & Ekonomi & F & $\mathbf{\%}$ \\
\hline 1. & Mendukung & 69 & 69,7 \\
2. & Tidak Mendukung & 30 & 30,3 \\
\hline & Total & $\mathbf{9 9}$ & $\mathbf{1 0 0}$
\end{tabular}

Berdasarkan data dari tabel diatas menunjukkan bahwa dari 99 responden PUS diperoleh ekonomi termasuk dalam kelompok mendukung sebanyak 69 orang $(69,7 \%)$ dan termasuk dalam kelompok tidak mendukung yaitu sebanyak 30 orang $(30,3 \%)$.

\section{Pengetahuan}

Tabel 4. Distribusi Frekuensi Pengetahuan di Kecamatan Bukit Kabupaten Bener Meriah

\begin{tabular}{c|c|c|c} 
No & Pengetahuan & $\mathbf{f}$ & $\mathbf{\%}$ \\
\hline 1. & Baik & 83 & 83,8 \\
2. & Tidak Baik & 16 & 16,2 \\
\hline & Total & $\mathbf{9 9}$ & $\mathbf{1 0 0}$
\end{tabular}

Dari tabel diatas menunjukkan bahwa dari 99 responden PUS diperoleh pengetahuan termasuk dalam kelompok mendukung sebanyak 83 orang $(83,8 \%)$ dan termasuk dalam kelompok tidak mendukung yaitu sebanyak 16 orang $(16,2 \%)$.

\section{Nilai Anak}

Tabel 5. Distribusi Frekuensi Nilai Anak di Kecamatan Bukit Kabupaten Bener Meriah

\begin{tabular}{c|c|c|c} 
No & Nilai Anak & f & $\mathbf{\%}$ \\
\hline 1. & Nilai Positif & 56 & 56,6 \\
2. & Nilai Negatif & 43 & 43,4 \\
\hline & Total & $\mathbf{9 9}$ & $\mathbf{1 0 0}$ \\
& Berdasarkan & tabel & diatas
\end{tabular}

menunjukkan bahwa dari 99 responden PUS diperoleh nilai anak termasuk dalam kelompok nilai positif sebanyak 56 orang $(56,6 \%)$ dan termasuk dalam kelompok nilai negatif yaitu sebanyak 43 orang $(43,4 \%)$.

\section{Penggunaan Kontrasepsi}


Tabel 6. Distribusi Frekuensi Penggunaan Kontrasepsi di Kecamatan Bukit Kabupaten Bener Meriah

\begin{tabular}{c|c|c|c} 
No & $\begin{array}{c}\text { Penggunaan } \\
\text { Kontrasepsi }\end{array}$ & $\mathbf{f}$ & $\mathbf{\%}$ \\
\hline 1. & Mendukung & 49 & 49,5 \\
2. & Tidak Mendukung & 50 & 50,5 \\
\hline & Total & $\mathbf{9 9}$ & $\mathbf{1 0 0}$ \\
& Berdasarkan & tabel & diatas
\end{tabular}
menunjukkan bahwa dari 99 responden PUS diperoleh penggunaan kontrasepsi termasuk dalam kelompok mendukung sebanyak 49 orang $(49,5 \%)$ dan termasuk dalam kelompok tidak mendukung yaitu sebanyak 50 orang $(50,5 \%)$.
Tabel 7. Distribusi Frekuensi Pengetahuan di Kecamatan Bukit Kabupaten Bener Meriah

\begin{tabular}{|c|c|c|c|}
\hline No & $\begin{array}{c}\text { Penentuan } \\
\text { Jumlah Anak }\end{array}$ & $\mathbf{F}$ & $\%$ \\
\hline 1. & $\leq 2$ & 30 & 30,3 \\
\hline 2. & $>2$ & 69 & 69,7 \\
\hline & Total & 99 & 100 \\
\hline
\end{tabular}
dari 99 responden PUS diperoleh penentuan jumlah anak termasuk dalam kelompok $\leq 2$ sebanyak 30 orang $(83,8 \%)$ dan termasuk dalam kelompok > 2 yaitu sebanyak 69 orang $(69,7 \%)$.

\section{Penentuan Jumlah Anak}

\section{B. Bivariat}

1. Hubungan DukunganKeluarga dengan Penentuan Jumlah Anak di Kecamatan Bukit Kabupaten Bener Meriah

\begin{tabular}{|c|c|c|c|c|c|c|c|c|}
\hline \multirow{3}{*}{ No } & \multirow{3}{*}{ Dukungan Keluarga } & \multicolumn{4}{|c|}{$\begin{array}{c}\text { Penentuan Jumlah } \\
\text { Anak }\end{array}$} & \multirow{2}{*}{\multicolumn{2}{|c|}{ Jumlah }} & \multirow{3}{*}{$\begin{array}{c}P \\
\text { value }\end{array}$} \\
\hline & & \multicolumn{2}{|c|}{$\leq 2$} & \multicolumn{2}{|c|}{$>2$} & & & \\
\hline & & $\mathbf{F}$ & $\%$ & f & $\%$ & f & $\%$ & \\
\hline 1. & Mendukung & 18 & 18,2 & 20 & 20,2 & 38 & 8,4 & \\
\hline 2. & Tidak Mendukung & 12 & 12,1 & 49 & 49,5 & 61 & 1,1 & 0,007 \\
\hline \multicolumn{2}{|c|}{ Total } & 30 & 30,3 & 69 & 69,7 & 99 & 100 & \\
\hline
\end{tabular}

Berdasarkan tabel hasil tabulasi silang diatas menunjukkan bahwa dari 38 orang $(38,4 \%)$ berada pada kelompok mendukung dimana sebanyak 18 orang $(18,2 \%)$ memiliki anak $\leq 2$ dan 20 orang $(20,2 \%)$ memiliki anak $>2$. Sedangkan responden yang termasuk dalam kelompok tidak mendukung sebanyak 61 orang $(61,6 \%)$ dimana 12 orang $(12,1 \%)$ memiliki anak $\leq 2$ dan 49 orang $(49,5 \%)$ memiliki anak $>2$.

Hasil uji statistik chi-square antara variabel dukungan keluarga dengan penentuan jumlah anak menunjukkan nilai $\mathrm{p}$ value $(0,007)<\alpha(0,05)$, yang artinya ada hubungan faktor dukungan keluarga dengan penentuan jumlah anak dalam keluarga di Kecamatan Bukit Kabupaten Bener Meriah.

2. Hubungan Sosial Budaya /Kepercayaan dengan Penentuan Jumlah Anak di Kecamatan Bukit Kabupaten Bener Meriah

\begin{tabular}{|c|c|c|c|c|c|c|c|c|}
\hline \multirow{3}{*}{ No } & \multirow{3}{*}{$\begin{array}{l}\text { Sosial Budaya/ } \\
\text { Kepercayaan }\end{array}$} & \multicolumn{4}{|c|}{$\begin{array}{c}\text { Penentuan Jumlah } \\
\text { Anak }\end{array}$} & \multirow{2}{*}{\multicolumn{2}{|c|}{ Jumlah }} & \multirow{3}{*}{$\underset{\text { value }}{P}$} \\
\hline & & \multicolumn{2}{|c|}{$\leq 2$} & \multicolumn{2}{|c|}{$>2$} & & & \\
\hline & & $\mathbf{F}$ & $\%$ & $\mathbf{f}$ & $\%$ & $\mathbf{f}$ & $\%$ & \\
\hline $\begin{array}{l}1 . \\
2 .\end{array}$ & $\begin{array}{l}\text { Mendukung } \\
\text { Tidak Mendukung }\end{array}$ & $\begin{array}{l}24 \\
6\end{array}$ & $\begin{array}{l}4,2 \\
6,1\end{array}$ & $\begin{array}{l}18 \\
51\end{array}$ & $\begin{array}{l}18,2 \\
51,5\end{array}$ & $\begin{array}{l}42 \\
57\end{array}$ & $\begin{array}{l}42,4 \\
57,6\end{array}$ & 0,00 \\
\hline & Total & 30 & $\mathbf{0 , 3}$ & 69 & 69,7 & 99 & 100 & \\
\hline
\end{tabular}


Berdasarkan tabulasi silang diatas menunjukkan bahwa dari 42 orang $(42,4 \%)$ berada pada kelompok mendukung dimana sebanyak 24 orang (18,2\%) memiliki anak $\leq 2$ dan 18 orang $(18,2 \%)$ memiliki anak $>2$. Sedangkan responden yang termasuk dalam kelompok tidak mendukung sebanyak 57 orang $(57,6 \%)$ dimana 6 orang $(6,1 \%)$ memiliki anak $\leq 2$ dan 51 orang $(51,5 \%)$ memiliki anak $>2$.

Hasil uji statistik chi-square antara variabel sosial budaya/kepercayaan dengan penentuan jumlah anak menunjukkan nilai $p$ value $(0,000)<\alpha(0,05)$, yang artinya ada hubungan faktor sosial budaya/kepercayaan dengan penentuan jumlah anak dalam keluarga.

3. Hubungan Ekonomi dengan Penentuan Jumlah Anak di Kecamatan Bukit Kabupaten Bener Meriah

\begin{tabular}{|c|c|c|c|c|c|c|c|c|}
\hline \multirow{3}{*}{ No } & \multirow{3}{*}{ Ekonomi } & \multicolumn{4}{|c|}{$\begin{array}{c}\text { Penentuan Jumlah } \\
\text { Anak }\end{array}$} & \multirow{2}{*}{\multicolumn{2}{|c|}{ Jumlah }} & \multirow{3}{*}{$\begin{array}{l}P \\
\text { value }\end{array}$} \\
\hline & & \multicolumn{2}{|c|}{$\leq 2$} & \multicolumn{2}{|c|}{$>2$} & & & \\
\hline & & f & $\%$ & $\mathbf{F}$ & $\%$ & $\mathbf{F}$ & $\%$ & \\
\hline 1. & Mendukung & 26 & 26,3 & 43 & 43,4 & 69 & 69,7 & 0 \\
\hline 2. & Tidak Mendukung & 4 & 4,0 & 26 & 26,3 & 30 & 30,3 & 0,029 \\
\hline \multicolumn{2}{|c|}{ Total } & 30 & 30,3 & 69 & 69,7 & 99 & 100 & \\
\hline
\end{tabular}

Berdasarkan hasil tabulasi silang diatas menunjukkan bahwa dari 69 orang $(69,7 \%)$ berada pada kelompok mendukung dimana sebanyak 26 orang $(26,3 \%)$ memiliki anak $\leq 2$ dan 43 orang $(43,4 \%)$ memiliki anak $>2$. Sedangkan responden yang termasuk dalam kelompok tidak mendukung sebanyak 30 orang $(30,3 \%)$ dimana 4 orang $(4,0 \%)$ memiliki anak $\leq 2$ dan 26 orang $(26,3 \%)$ memiliki anak $>2$.

Hasil uji statistik chi-square antara variabel ekonomi dengan penentuan jumlah anak menunjukkan nilai $p$ value $(0,029)<\alpha(0,05)$, yang artinya ada hubungan faktor ekonomi dengan penentuan jumlah anak dalam keluarga.

\section{Hubungan Pengetahuan dengan Penentuan Jumlah Anak}

\begin{tabular}{|c|c|c|c|c|c|c|c|c|}
\hline \multirow{3}{*}{ No } & \multirow{3}{*}{ Pengetahuan } & \multicolumn{4}{|c|}{$\begin{array}{c}\text { Penentuan Jumlah } \\
\text { Anak }\end{array}$} & \multirow{2}{*}{\multicolumn{2}{|c|}{ Jumlah }} & \multirow{3}{*}{$\begin{array}{c}P \\
\text { value }\end{array}$} \\
\hline & & \multicolumn{2}{|c|}{$\leq 2$} & \multicolumn{2}{|c|}{$>2$} & & & \\
\hline & & f & $\%$ & f & $\%$ & $\mathbf{F}$ & $\%$ & \\
\hline $\begin{array}{l}1 . \\
2 .\end{array}$ & $\begin{array}{l}\text { Baik } \\
\text { Tidak Baik }\end{array}$ & $\begin{array}{l}26 \\
4\end{array}$ & $\begin{array}{l}26 \\
4,0\end{array}$ & $\begin{array}{l}57 \\
12\end{array}$ & $\begin{array}{l}57,6 \\
12,1\end{array}$ & $\begin{array}{l}83 \\
16\end{array}$ & $\begin{array}{l}83,8 \\
16,2\end{array}$ & 0,836 \\
\hline \multicolumn{2}{|c|}{ Total } & 30 & 30,3 & 69 & 9,7 & 99 & 100 & \\
\hline
\end{tabular}

Berdasarkan tabel hasil tabulasi silang menunjukkan bahwa dari 83 orang $(83,8 \%)$ berada pada kelompok pengetahuan baik dimana sebanyak 26 orang $(26,3 \%)$ memiliki anak $\leq 2$ dan 57 orang $(57,6 \%)$ memiliki anak $>2$. Sedangkan responden yang termasuk dalam kelompok pengetahuan tidak baik sebanyak 16 orang $(16,2 \%)$ dimana 4 orang $(4,0 \%)$ memiliki anak $\leq 2$ dan 12 orang $(12,1 \%)$ memiliki anak $>2$.

Hasil uji statistik chi-square antara variabel pengetahuan dengan penentuan jumlah anak menunjukkan nilai $\mathrm{p}$ value $(0,836)>\alpha(0,05)$, yang artinya tidak ada hubungan faktor pengetahuan dengan penentuan jumlah anak $\leq 2$ dalam keluarga.

5. Hubungan Nilai Anak dengan Penentuan Jumlah Anak

\begin{tabular}{|c|c|c|c|c|c|c|c|c|}
\hline \multirow{3}{*}{ No } & \multirow{3}{*}{ Nilai Anak } & \multicolumn{4}{|c|}{$\begin{array}{c}\text { Penentuan Jumlah } \\
\text { Anak }\end{array}$} & \multirow{2}{*}{\multicolumn{2}{|c|}{ Jumlah }} & \multirow{3}{*}{$\begin{array}{l}P \\
\text { value }\end{array}$} \\
\hline & & $\leq$ & & $>$ & & & & \\
\hline & & f & $\%$ & $\mathbf{f}$ & $\%$ & f & $\%$ & \\
\hline
\end{tabular}




\begin{tabular}{l|l|l|l|l|l|l|l|l}
\hline 1. & Nilai Positif & 24 & 24,2 & 32 & 2,2 & 56 & 56,6 & \multirow{2}{*}{0,004} \\
2. & Nilai Negatif & 6 & 6,1 & 37 & 7,4 & 43 & 43,4 & \\
\hline \multicolumn{1}{r|}{ Total } & $\mathbf{3 0}$ & $\mathbf{3 0 , 3}$ & $\mathbf{6 9}$ & $\mathbf{9 , 7}$ & $\mathbf{9 9}$ & $\mathbf{1 0 0}$ &
\end{tabular}

Berdasarkan tabel hasil tabulasi silang diatas menunjukkan bahwa dari 56 orang $(56,6 \%)$ berada pada kelompok nilai positif dimana sebanyak 24 orang $(24,2 \%)$ memiliki anak $\leq 2$ dan 32 orang $(32,2 \%)$ memiliki anak $>2$. Sedangkan responden yang termasuk dalam kelompok nilai negatif sebanyak 43 orang $(43,4 \%)$ dimana 6 orang $(6,1 \%)$ memiliki anak $\leq 2$ dan 37 orang $(37,4 \%)$ memiliki anak $>2$.

Hasil uji statistik chi-square antara variabel nilai anak dengan penentuan jumlah anak menunjukkan nilai $p$ value $(0,004)<\alpha(0,05)$, yang artinya ada hubungan faktor nilai anak dengan penentuan jumlah anak $\leq 2$ dalam keluarga.

\section{Hubungan Penggunaan Kontrasepsi dengan Penentuan Jumlah Anak}

\begin{tabular}{|c|c|c|c|c|c|c|c|c|}
\hline \multirow{3}{*}{ No } & \multirow{3}{*}{$\begin{array}{l}\text { Penggunaan } \\
\text { Kontrasepsi }\end{array}$} & \multicolumn{4}{|c|}{$\begin{array}{l}\text { Penentuan Jumlah } \\
\text { Anak }\end{array}$} & \multirow{2}{*}{\multicolumn{2}{|c|}{ Jumlah }} & \multirow{3}{*}{$\begin{array}{l}P \\
\text { value }\end{array}$} \\
\hline & & \multicolumn{2}{|c|}{$\leq 2$} & \multicolumn{2}{|c|}{$>2$} & & & \\
\hline & & f & $\%$ & f & $\%$ & $\mathbf{F}$ & $\%$ & \\
\hline 1. & Mendukung & 25 & 25,3 & 24 & 24,2 & 49 & 49 , & \\
\hline 2. & Tidak Mendukung & 5 & 5,1 & 45 & 45,5 & 50 & $\begin{array}{l}5 \\
50, \\
5\end{array}$ & 0,001 \\
\hline & Total & 30 & $\mathbf{3 0 , 3}$ & 69 & 69,7 & 99 & 100 & \\
\hline
\end{tabular}

Berdasarkan tabel hasil tabulasi silang diatas menunjukkan bahwa dari 49 orang $(49,5 \%)$ berada pada kelompok mendukung dimana sebanyak 25 orang $(25,3 \%)$ memiliki anak $\leq 2$ dan 24 orang $(24,2 \%)$ memiliki anak $>2$. Sedangkan responden yang termasuk dalam kelompok tidak mendukung sebanyak 50 orang $(50,5 \%)$ dimana 5 orang $(5,1 \%)$ memiliki anak $\leq 2$ dan 45 orang $(45,5 \%)$ memiliki anak $>2$.

Hasil uji statistik chi-square antara variabel penggunaan kontrasepsi dengan penentuan jumlah anak menunjukkan nilai $\mathrm{p}$ value $(0,001)<\alpha(0,05)$, yang artinya ada hubungan faktor penggunaan kontrasepsi dengan penentuan jumlah anak $\leq 2$ dalam keluarga.

\section{Multivariat}

Tabel Uji Binary Logistic Faktor-Faktor yang Memengaruhi Penentuan Jumlah Anak dalam Keluarga di Kecamatan Bukit Kabupaten Bener Meriah

\begin{tabular}{l|l|c|c|l|l|l} 
No & \multicolumn{1}{|c|}{ Variabel } & B & $\begin{array}{c}\boldsymbol{P} \\
\text { value }\end{array}$ & Exp.(B) & Lower & Upper \\
& & & & & \\
\hline 1 & Dukungan Keluarga & 2,151 & 0,004 & 8,593 & 2,016 & 36,627 \\
2 & Sosial Budaya & 2,888 & 0,001 & 17,956 & 3,918 & 82,285 \\
3 & Ekonomi & 2,242 & 0,017 & 9,409 & 1,486 & 59,567 \\
4 & Nilai Anak & 1,410 & 0,055 & 4,095 & 0,971 & 17,267 \\
5 & Peggunaan Kontrasepsi & 2,639 & 0,001 & 14,005 & 3,052 & 64,258
\end{tabular}

Berdasarkan hasil penelitian mengenai faktor-faktor yang memengaruhi penentuan jumlah anak $\leq 2$ dalam keluarga dengan menggunakan uji statistik logistic regression didapatkan bahwa variabel independen yang memiliki nilai sig. $<0,05$ adalah dukungan keluarga dengan nilai sig. 0,004 , sosial budaya dengan nilai sig. 0,001 , ekonomi dengan nilai sig. 0,017dan penggunaan kontrasepsi dengan nilai sig. 0,001 . 
Kemudian variabel independen yang memiliki nilai sig. $<0,05$ dilakukan pengujian yang sama,diperoleh :

\begin{tabular}{c|l|c|c|c|c|l} 
No & \multicolumn{1}{|c|}{ Variabel } & B & $\begin{array}{c}\boldsymbol{P} \\
\text { value }\end{array}$ & $\begin{array}{c}\text { Exp. } \\
\text { (B) }\end{array}$ & Lower & Upper \\
\hline 1. & Dungan Keluarga & 1,979 & 0,005 & 7,237 & 1,831 & 28,602 \\
2. & Sosial Budaya & 3,136 & 0,001 & 23,009 & 5,193 & 101,935 \\
3. & Ekonomi & 2,254 & 0,016 & 9,524 & 1,525 & 59,467 \\
4. & Peggunaan Kontrasepsi & 2,497 & 0,001 & 12,152 & 2,912 & 50,706
\end{tabular}

Hasil uji statistik Binary Logistic pada tabel diatas menunjukkan bahwa dari 4 variabel independen yang diuji hasilnya adalah dukungan keluarga dengan nilai $\operatorname{Exp}(\mathrm{B}) 7,237$ (CI : 95\%, 1,831-28,602), sosial budaya dengan nilai $\operatorname{Exp(B)~23,009~(CI~:~95\% ,~5,193-~}$ 101,935), ekonomi dengan nilai $\operatorname{Exp}(\mathrm{B}) 9,524$ (CI : 95\% 1,525-59,467) dan penggunaan kontrasepsi dengan nilai $\operatorname{Exp}(\mathrm{B}) 12,152$ (CI : 95\%, 2,912-50,706).

Besarnya pengaruh ditunjukkan dengan nilai EXP (B) atau disebut juga Odds Ratio (OR). Variabel dukungan keluarga dengan OR 7,237 maka keluarga PUS yang tidak mendukung keluarga berencana berpeluang 7,237 kali memiliki jumlah anak >2 dalam keluarga.

Variabel sosial budaya dengan OR 23,009 maka sosial budaya PUS yang tidak mendukung berpeluang 23,009 kali memiliki jumlah anak >2 dalam keluarga. Variabel ekonomi dengan OR 9,524 maka PUS yang memiliki ekonomi tidak mendukung berpeluang 9,524 kali memiliki jumlah anak $>2$ dalam keluarga. Variabel penggunaan kontrasepsi dengan OR 12,152 maka penggunaa kontrasepsi PUS yang tidak menggunakan kontrasepsi berpeluang 12,152 kali memiliki jumlah anak >2 dalam keluarga.

Dari hasil uji multivariat ini dapat diketahui bahwa sosial budaya adalah variabel yang paling dominan berpengaruh terhadap penentuan jumlah anak dalam keluarga dengan nilai koefisien regresi (B) yaitu 3,136 dengan nilai OR 23,009.

Hal ini menunjukkan bahwa faktor sosial budaya pada PUS yang tidak mendukung akan berpeluang 23,009 kali lebih besar untuk memiliki jumlah anak banyak (>2) dalam keluarga dibandingkan dengan sosial budaya yang mendukung, akan memiliki jumlah anak $\leq 2$ di Kecamatan Bukit Kabupaten Bener Meriah. 


\section{KESIMPULAN}

1. Berdasarkan hasil uji statistik dengan menggunakan uji chi-square diperoleh bahwa ada pengaruh faktor dukungan keluarga terhadap penentuan jumlah anak dalam keluarga, dengan nilai $\mathrm{p}=0,007$.

2. Berdasarkan hasil uji statistik dengan menggunakan uji chi-square diperoleh bahwa ada pengaruh faktor sosial budaya/kepercayaan terhadap penentuan jumlah anak dalam keluarga,dengan nilai $\mathrm{p}=0,00$.

3. Berdasarkan hasil uji statistik dengan menggunakan uji chi-square diperoleh bahwa ada pengaruh faktor ekonomi terhadap penentuan jumlah anak dalam keluarga, dengan nilai $\mathrm{p}=0,029$.

4. Berdasarkan hasil uji statistik dengan menggunakan uji chi-square diperoleh bahwa tidak ada pengaruh faktor pengetahuan terhadap penentuan jumlah anak dalam keluarga, dengan nilai $\mathrm{p}=0,836$.

5. Berdasarkan hasil uji statistik dengan menggunakan uji chi-square diperoleh bahwa ada pengaruh faktor nilai anak terhadap penentuan jumlah anak dalam keluarga, dengan nilai $\mathrm{p}=0,004$.

6. Berdasarkan hasil uji statistik dengan menggunakan uji chi-square diperoleh bahwa ada pengaruh faktor penggunaan kontrasepsi terhadap penentuan jumlah anak dalam keluarga, dengan nilai $\mathrm{p}=0,001$.

7. Berdasarkan hasil uji binary logistic menunjukkan bahwa variabel sosial budaya adalah variabel yang paling dominan berpengaruh terhadap penentuan jumlah anak dalam keluarga dengan nilai $\operatorname{Exp}(\mathrm{B}) \quad 23,009$ (CI : 95\%, 5,193-101,935). Hal ini menunjukkan bahwa faktor sosial budaya pada PUS yang tidak mendukung berpeluang 23,009 kali lebih besar untuk memiliki jumlah anak banyak (> 2 anak) dalam keluarga dibandingkan dengan sosial budaya PUS yang mendukung di Kecamatan Bukit Kabupaten Bener Meriah.

\section{REFERENSI}

BKKBN. (2012). Kebijakan Program Pokok Dan Kegiatan Bidang Layanan KB Dan Kesehatan Reproduksi. Jakarta.

BKKBN. (2012). Statistik Indonesia and Mancro Internasional Indonesia Demographic and Health Survey 2012. Jakarta.

BKKBN. (2015). Buku Profil Pendataan Keluarga Serta Program Kependudukan Dan KB Nasional. Jakarta.

BKKBN. (2012). Rencana Strategis Pembangunan Kependudukan Dan Keluarga Berencana tahun 2010-2014. Jakarta.

BKKBN. Total Fertility Rate antar Propinsi Dinkes $15 \quad$ Nopember 2016 http.//www.total-fertility-rate-antarprovinsi.org/tfr-html.

BPS. (2012). Badan Pusat Statistika Laju Pertumbuhan Penduduk . Jakarta.

Childinfo. (2011). A Global Overview Of Maternal Mortality, diunduh 20 April 2017http://www.chiddinfo.org/materna 1 mortalit.html.

Dinkes Aceh. Profil kesehatan Provinsi Aceh. (dokumen internet) 2012, (diunduh 20 April 2017) tersedia dari http//www.dinkessumut.go.it

Departemen Kesehatan Republik Indonesia. (2015). Data dan Informasi (Pusat data dan Informasi Krmenterian Republik Indonesia). Jakarta.

Kesuma, Fitria. (2010). Partisipasi Masyarakat Dalam Mengikuti Program Keluarga Berencana Di Desa Sidoharjo Kecamatan Polanharjo.

Klaten.(Skripsi). 2010. (diunduh 20 April 2019). Tersedia dari http://www.partisipasi-masyarakat dalam-mengikuti-program-keluarga berencana-di-desa-sidoharjo 
kecamatan-polanharjo-kabupaten

Klaten-tahun-2010.com

SUPAS. (2011). Maternal mortalityRatio diunduh $20 \quad$ April 2017 http://indonesia.supas.org/issues-andcallenges/maternal-mortality-ratio.

Singarimbun. (2019). Mengenai Nilai Anak Pada Masyarakat Jawa Dan Sunda Menemukan Adanya Variasi Nilai Anak Berdasarkan Pandangan Orang, diunduh 20 April 2019 repository, usu, ac, id. /bitstrem/123456789/37297/41 chapter\%201.pdf.

Zainuddin. (2011). Bonus Demografi Modal Pembangunan Bangsa Yang Sehat Dan Bermanfaat. Jakarta. 